$\xi=-1$

\title{
The critical thinking dispositions of students around coffee plantation area in solving algebraic problems
}

\author{
Kurniati, Dian ${ }^{1}$; Zayyadi, Moh ${ }^{2}$ \\ ${ }^{I}$ Department of Mathematic Education, University of Jember, Indonesia \\ ${ }^{2}$ Department of Mathematic Education, University of Madura, Indonesia \\ *Corresponding author E-mail: dian.kurniati@unej.ac.id
}

\begin{abstract}
The present study aimed at describing the dispositions of students around a coffee plantation in solving algebraic problems, especially those pertaining to fraction and comparison. Critical thinking disposition denotes the initial milestone to developing students' critical thinking skills. The study investigated four components of critical thinking dispositions, comprising of truth-seeking, open-mindedness, self-confidence, and inquisitiveness. The subjects under investigation were 45 students at the second grade of a junior high school situated around Garahan coffee plantation in Jember district, East Java, Indonesia. The study covered several phases, inter alia, (1) describing problems on Algebra to the students, (2) recording any activities of the research subjects when doing tasks given, (3) analyzing the students' answer sheets based on four components of critical thinking dispositions, (4) conducting method triangulation projected to confirm the preliminary findings on the students critical thinking dispositions, and (5) determining the students' critical thinking dispositions based on the results of direct observation, video recording, and interview. The study gained several findings related to the students' dispositions. First, the students' tendency in truth-seeking was characterized by their analysis on the problems given on themes regarding coffee. This prevented them from making mistakes as they checked some information, be it known or unknown, as the bases for problem solving. However, not every student was aware of what was unknown about the problem or what was required to solve the problem. Second, their tendency in open-mindedness was evinced by the fact that they were assured of their answer as they related it to their experience in planting coffee. Nevertheless, some students tended to ask their parent when they had to determine the amount of diameter comparison between two logs to be connected. Third, they tended to be confident in solving problems given as they had experienced the activities described in the problem when they assisted their parents in planting coffee, but still some students had yet to be sure of their answers as they lacked the experience in planting coffee. Lastly, they tended to possess sound inquisitiveness concerning various issues pertinent to solving algebraic problems, especially themed on coffee. They acquired the inquisitiveness by observing the actual activity in their environment. Nonetheless, their inquisitiveness could not be generalized to algebraic lessons at school.
\end{abstract}

Keywords: Critical Thinking Dispositions, Algebraic Problems, Coffee Plantation Area

\section{Introduction}

Critical thinking is a logical and reflective thinking skill required in determining what should be decided or what should be done [1]. Critical thinking is tremendously essential for all students at both primary and secondary education if they are to keep up with the 21 st century $[2,3]$. Partnerships for 21 st Century Skills strongly recommends that education is to put more emphasis on learning which strives to develop the 4Cs rather than content mastery. The Government of Indonesia through the Ministry of Education and Culture voices positive outlook on these recommendations Grappling with the very challenge, graduates of primary and secondary education programs are required to master creative thinking skills, coupled with the quality of being productive, independent, critical, collaborative, and communicative. Owing to the regulatory policy, all elementary and primary as well as secondary education institutions in Indonesia are required to develop these skills. This implies that all education stakeholders involved in an educational institution has to be called to work in tandem on the development of the 4 Cs to students.
However, in reality, critical thinking has yet to be developed to its outmost, either in the oversea countries or throughout Indonesia, as is the case in the school around Garahan coffee plantations [4, $5,6]$. The very issue makes it necessary to carry out an undertaking aimed to improve the critical thinking of students, especially those around the coffee plantation of Garahan, Jember, East Java, Indonesia. The process of improving and developing the critical thinking dispositions of the students is highly dependent on their understanding of the environment [4, 7]. Students who master critical thinking skills hardly rush in making decisions when they encounter a problem which demands higherorder thinking $[1,8]$. They always resort to fine reasoning. They always remain skeptical, strives to find out actual conditions, analyze them carefully and comprehensively, put a lot of thoughts on the conditions, and emphasize facts rather than opinions. They always consider the best decision prior to taking action [9]. It is natural therefore that students with critical thinking are considered to have better chances of success in everyday life as well as in their academic assignment [10]. Referring to the abovementioned discussion, the present study deems it necessary to make an effort 
devoted to improving students' critical thinking, especially around the coffee plantations.

One research suggests that student's critical thinking skills will increase when the disposition of critical thinking is satisfactory and fulfils all the critical thinking disposition components $[6,11$, 12]. The dispositions of critical thinking is one of two critical thinking components $[1,11,13,14]$. The critical thinking disposition itself denotes a person's tendency to behave or act when facing a problem $[1,2,15]$. Therefore, it is necessary to encourage the students around the coffee plantations to develop their critical thinking dispositions through problem solving process on daily-life issues pertinent to coffee. In this study, the critical thinking disposition of the students around coffee plantations can be scrutinized from the initial process they perform when encountering algebraic problems related to coffee.

There are several studies which shed lights on the indicators and components of critical thinking dispositions. As a corollary, some experts have developed some indicators of people who have critical thinking dispositions. People who have this critical thinking disposition tend to ask for clarity, work diligently, seek information persistently, promote rationality, ponder possible impacts resulting from their action, and put considerate emphasis on precision [16]. Another expert, Lai, says that people who have a critical thinking disposition tend to be open-minded, fairminded, rational (reasoned), inquisitive, curious (strive to be wellinformed), and flexible [17]. According to Kokdemir [18], people with critical-thinking dispositions tend to be concerned with truth, open-minded, analytical, systematic, confident, and inquisitive [18]. That notion is slightly different from that of Ennis's disposition components, which encompasses truth-seeking, openmindedness, analytical, systematic, self-confident, inquisitive, and mature [1].

In this study the components of critical thinking disposition under investigation pertain to truth-seeking, open-mindedness, selfconfidence, and inquisitiveness. With regard to the first component, when operated in solving problems, students are said to have the attitude of truth-seeking if they carry out an attempt to analyze problems based on their experience and knowledge prior to resorting to a proper solution. If they have not found a correct decision, then they will try to find another way to find the solution to the problem at hand. As in the case of the second component, open-minded, this notion is evident on students willing to hear and accept opinions from others if the answer they listen to is true and coupled with some appropriate reasons. Open-mindedness opens student's mind to the possibility that an idea, view, data, theory, and conclusion can be either right or wrong. Student is said to possess the fourth component, confidence in critical thinking, when he shows confidence in the process of inquiry and believes one opinion he considers true and corroborated by critical thinking. As regard to the last component, students are said to have curiosity when their attitude displays curiosity about something or a growing issue. This is usually actualized by raising questions and also carefully listening to the steps of thinking expressed by friends and trying to find ideas from media for problem solving, in addition to resources from friends and teachers.

\section{Research Method}

This research was qualitative descriptive in nature, which described in depth the disposition of critical thinking of students around the coffee plantation in solving algebraic problem. The type of problem given to the research subjects was a question, which was open to more than one answer, involving one question in each problem. The critical thinking disposition components observed were truth-seeking, open-mindedness, self-confidence, and inquisitiveness. The subjects under investigation were 45 students at the second grade of a junior high school situated around Garahan coffee plantation in Jember district, East Java, Indonesia. The study covered several phases, inter alia, (1) describing problems on Algebra to the students, (2) recording any activities of the research subjects when doing tasks given, (3) analyzing the students' answer sheets based on four components of critical thinking dispositions, (4) conducting method triangulation projected to confirm the preliminary findings on the students critical thinking dispositions, and (5) determining the students' critical thinking dispositions based on the results of direct observation, video recording, and interview.

\section{Results and discussion}

There were fifteen junior high school students who did not have good critical thinking disposition. These students tended to pay less attention to the information given to the problem they dealt with. As such, many students of these made mistakes in solving the problem. The students did not resort to their experience when directly involved in the process of coffee farming. As a result, their critical thinking disposition component of truth-seeking could hardly evolve, because the students were incapable of showing analytical stance on the information upon problem solving.

Furthermore, when scrutinized on the critical thinking disposition components germane to open-mindedness, these fifteen students were not able to provide any other means or alternative to the solutions they had proposed. However, when given a problem that they thought to be difficult, these students resorted to asking their parents who worked as farmers or coffee garden workers. So, students could ask for their parents' advice and experience, which would be of great help in dealing with the problem solving. Therefore, these 15 students posed satisfactory open-mindedness. The study also found out that these fifteen students felt some disbelief in them because they did not experience the process of farming coffee directly. In addition, the students were also unsure of the answers they came up with. However, the tendency in curiosity was very good. This was because students tried to discuss with their parents to solve the problem and discuss with the teacher and some other friends.

The findings of these fifteen students were slightly different from those of the other twenty students. The difference lied in the tendency of behavior in seeking truth and the openness in answering questions. The twenty students always checked the truth of the information given in problem by analyzing what were known and unknown thereof. In addition, they also probed the first things unknown, yet essential to solving the problem. After ensuring that the information on the given problem was complete, they tried to solve the problem in clear and detailed stages. The completion was based on their experience when farming coffee in their daily life. These students worked on not one, yet two alternatives of problem solving. They applied different angles when attempting to solve problem pertinent to cutting the coffee rod, so that there were two answers generated. Furthermore, with regard to their cognitive tendency in seeking information and curiosity, the students tended to rely on information from their parents and teachers who were knowledgeable about the process of farming coffee.

The next ten students showed good critical thinking dispositions because the four components of critical thinking disposition were evident when they were given problems about the process of farming coffee. The tendency of these students upon finding the truth regarding the problems at hand was to check the information provided and consulted it to the teacher. The information they came across was the correct information as presented in the problems, and when there was an unknown details in the problem, they tried to analyze it for necessary information. In addition, the students also tried to find another solution to determining the diameter comparison of two coffee tree stalks. Another solution was obtained from discussions and information from their parents, which was concerned with the process of merging two coffee stalks. Thus, the answers obtained from the given problem vary 
greatly depending on the age and diameter of the coffee rod to be joined.

The process of accruing students' curiosity and confidence was very good. Students were very convinced of the answers they provided upon solving the problems. This was because they already had first-hand experience on the process of farming coffee. In addition, students also tried to find solutions from books which were were often used by teachers in explaining the material on grafting coffee plants as found in the school library. Students also conducted discussions and probed information from parents and coffee garden owners around their dwellings.

Corroborated by abovementioned findings, the present study has shed lights on the following concerns. First, the students' tendency in truth-seeking was characterized by their analysis on the problems given on themes regarding coffee. This prevented them from making mistakes as they checked some information, be it known or unknown, as the bases for problem solving. However, not every student was aware of what was unknown about the problem or what was required to solve the problem. Second, their tendency in open-mindedness was evinced by the fact that they were assured of their answer as they related it to their experience in planting coffee. Nevertheless, some students tended to ask their parent when they had to determine the amount of diameter comparison between two stalks to be connected. Third, they tended to be confident in solving problems given as they had experienced the activities described in the problem when they assisted their parents in planting coffee, but still some students had yet to be sure of their answers as they lacked the experience in planting coffee. Lastly, they tended to possess sound inquisitiveness concerning various issues pertinent to solving algebraic problems, especially themed on coffee. They acquired the inquisitiveness by observing the actual activity in their environment. Nonetheless, their inquisitiveness could not be generalized to algebraic lessons at school.

The research results were in line with those of former researches, which have reveal that the students are basically skilled in developing high-level thinking skills in solving problems related to coffee even though their performance has not been maximized ${ }^{4}$. In addition, the findings are also in line with other studies, which argue that students' disposition in critical thinking is very much dependent on the question or theme of given questions $[19,20]$. In this case, the theme of the given problem has to comply with the students' environment in their everyday life, so that the critical thinking disposition has the chance to develop and the students thus are able to explore problems related to their daily life. Moreover, students at the age of 15 have yet to develop their critical thinking disposition optimally $[4,6,11,19,20]$. These former studies support the results of this study, discovering that only two disposition components were developed, although only at minor extent, as was the case of self-confidence and curiosity. Based on these findings, the present study has highlighted the importance of rationales to determining the themes within which one's disposition in critical thinking is detected and explored. The theme, as a result, has to be adapted to his daily environment. Moreover, further research is required to delve into 3 (three) other components of critical thinking disposition which have not been investigated in the study. Finally, similar research can be done to different subjects who have the same culture and background as those in this study.

\section{Conclusion}

The present study has drawn the following conclusions. First, the students' tendency in truth-seeking was characterized by their analysis on the problems given on themes regarding coffee. Second, the students' tendency in open-mindedness was evinced by the fact that they were assured of their answer as they related it to their experience in planting coffee. In addition, the students tended to be confident in solving problems given as they had experienced the activities described in the problem when they assisted their parents in planting coffee, but still some students had yet to be sure of their answers as they lacked the experience in planting coffee. Lastly, the students tended to possess sound inquisitiveness concerning various issues pertinent to solving algebraic problems, especially themed on coffee.

\section{References}

[1] Ennis RH (1996), Critical Thinking. United State of America: Prentice-Hall

[2] Dilley A, Kaufman JC, Kennedy C \& Plucker JA (2015), What We Know About Critical Thinking Part of the 4Cs Research Series. US: Partnership for 21 st Century Skills.

[3] “UNDANG-UNDANG REPUBLIK INDONESIA," 2005. [Online]. Available: http://peraturan.go.id/uu/nomor-14-tahun2005.html. [Accessed: 13-Nov-2017].

[4] Suratno \& Kurniati D (2017), "The Process Of Students' Higher Order Thinking Around Coffee Plantation Area In Solving OpenEnded Problems Related To Coffee Theme," Turkish Online Journal of Educational Technoogyl, Desember, no. Special Issues, 521-524.

[5] Lin SW (2016), "A Longitudinal Study for Types and Changes of Students' Mathematical Disposition," Universal Journal Educationa Research, 4(8), 1903-1911.

[6] Aizikovitsh-Udi E \& Cheng D (2015), "Developing Critical Thinking Skills from Dispositions to Abilities: Mathematics Education from Early Childhood to High School," Creative Education, 6, 455-462, 2015.

[7] Suratno \& Kurniati D (2017), "Performance profile of the coffee plantation area students in solving the math-science problem," Advanced Science Letters, 23(2).

[8] Yenice N (2011), "Investigating pre-service science teachers' critical thinking dispositions and problem solving skills in terms of different variables," Educational Research Review.

[9] Kang FL (2015), "Contribution of Emotional Intelligence towards Graduate Students' Critical Thinking Disposition," International Journal Education Literacy Studies. ISSN Aust. Int. Acad. Cent., 3(4), 2202-9478.

[10] As 'ari, AR, Mahmudi A \& Nuerlaelah E (2017), "Our Prospective Mathematic Teachers Are Not Critical Thinkers Yet," Journal Mathematics Education, 8(2), 145-156.

[11] Chukwuyenum AN, "Impact of Critical thinking on Performance in Mathematics among Senior Secondary School Students in Lagos State," IOSR Journal Research Mathematics Education, 3(5), 2320-7388.

[12] Clark LM et al.(2014), "Teacher Characteristics Associated With Mathematics Teachers' Beliefs and Awareness of Their Students' Mathematical Dispositions," Source Journal Research Mathematics Education, 45(2), 246-284.

[13] Lampert N (2007), "Critical Thinking Dispositions As An Outcome Of Undergraduate Education," Source Journal General Education, 56(1), 17-33..

[14] Biber AC, Tuna A \& Incikabi L (2013), "An investigation of critical thinking dispositions of mathematics teacher candidates," Educational Research, 4(2), 2141-5161.

[15] ŽivkoviE S (2016), "A Model of Critical Thinking as an Important Attribute for Success in the 21st Century," Procedia Soc. Behav. Sci.

[16] Facione PA, Sánchez CA, Facione NC \& Gainen J (1995), “The Disposition Toward Critical Thinking," Source Journal General Education, 44(1), 1-25.

[17] Mena-Lorca A \& Parraguez AMM (2016), "Mental constructions for the group isomorphism theorem," Mathematics Education.

[18] Emİr S (2013), "Contributions of Teachers ' Thinking Styles to Critical Thinking Dispositions ( Istanbul-Fatih Sample )," 13(1), 337-347.

[19] Kalelioğlu F \& Gülbahar Y (2014), “The Effect of Instructional Techniques on Critical Thinking and Critical Thinking Dispositions in Online Discussion," Source Journal Educational Technology Social., 17(171), 248-258.

[20] Özyurt O (2015), "Examining the critical thinking dispositions and the problem solving skills of computer engineering students," Eurasia Journal Mathematics Science Technology Education.. 